\title{
SEROLOGICAL AND MOLECULAR DIFFERENTIATION BETWEEN BRUCELLA AND YERSINIA ENTEROCOLITICA O:9 INFECTIONS IN CATTLE
}

\author{
NADIA A. SHALABY ${ }^{*}$ JEHAN A. GAFER ${ }^{* *}$ and BADRAN M.A. BADRAN ${ }^{* * *}$ \\ *Brucella Department, Animal Health Research Institue Dokki, Giza. \\ ***Botechnology Research Unit, Animal Reproduction Research Institute, Giza. \\ *** Consultant of Vet. Infectious Disease, Directorate of Vet. Med. Sharkia \\ Email: (jehan.gafer@gmail.com)
}

\section{ABSTRACT}

Brucellosis is one of the world's major zoonoses that still has veterinary, public health and economic concern in many parts of the world. In livestock, brucellosis is the major

Received at: 4/9/2013 impediment for trade and export. In this work a total of 118 different samples (45 serum samples, 45 blood samples, stomach contents of 18 aborted feati and 10 fecal samples) were collected from 45 diseased and apparently healthy cows at selected veterinary clinics at El-Sharkia governorate. The serum samples were subjected to

Accepted: 26/9/2013 investigation by different serological methods (Rose Bengal, BAPAT, CFT and ELISA) for detection of bovine brucellosis. While, molecular differentiation between Brucella and Yersenia enterocolitica O:9 were made on blood samples, stomach contents and fecal samples of sero positive animals for brucellosis using multiplex PCR assay. The results revealed that 26 out of 45 serum samples were positive for brucellosis, as detected by ELISA while 19 samples gave positive amplification of 223bp for Brucella and seven positive amplification of 325bp for Yersinia representing $26.92 \%$ of total brucellosis seropositives of which two samples $(7.69 \%)$ were positive for both Yersinia and Brucella as tested by multiplex PCR assay. Therefore, we concluded that multiplex PCR proved to be a reliable molecular method for differentiation between Brucella and Yersinia as rapid diagnostic tool directly from clinical specimens.

Key words: Multiplex PCR, Brucella, Yersinia enterocoliticaO:9, Serological investigation.

\section{INTRODUCTION}

Brucellae are gram-negative facultative intracellular bacteria causing brucellosis, which remains a zoonosis of worldwide public health and economic importance (Marcin et al., 2012). The economic impact of brucellosis in animals can be devastating (Gorvel 2008), especially in developing countries (Erika et al., 2012).

Y. enterocolitica serotype 0:9 is one of the human pathogenic serotypes, which can also infect animals, generally without causing any symptoms. Pigs, sheep, and cattle can be carriers of pathogenic serotypes of $Y$. enterocolitica in their intestinal flora. Prevalence of $Y$. enterocolitica seems to be on the rise, at least in cattle, as it was rarely seen before the 1990 and since then has been regularly isolated (Erika et al., 2012).

Brucella, however, is a slow growing organism and cultures are rarely positive before the fourth day of incubation. Usually cultures become positive between the first and third week, and should be kept for at least 45 days before the culture can be concluded to be negative for Brucella (Henk and Manzoor 2005).
Moreover, the conventional isolation and identification procedures for the detection of $Y$. enterocolitica clinical samples are time consuming taking at least 2-4 weeks owing to the cold enrichment procedures being followed and require several phenotypic assays for the differentiation of pathogenic and non-pathogenic yersiniae (Kapperud 1991; Lübeck et al., 2003 and Balakrishna et al., 2012).

Although, many cross-reacting microorganisms may yield false positive results for Bovine brucellosis, only Yersinia enterocolitica O:9 is a significant cause of false-positive serological reactions (FPSR) in the diagnosis of bovine brucellosis (Gerbier et al., 1997). The gradual increase during 1990 in herds infected with Yersinia enterocolitica serotype 0:9 has created an international problem in laboratory diagnosis of brucellosis (Cheasty et al., 1998; Lübeck et al., 2003).

Eradication of brucellosis is based on the serological testing of animals and the subsequent culling of those that are seropositive for antibodies to Brucella. Thus, the specificity of the serological tests used is of paramount importance, (Raúl et al., 2005) and the 
need for accurate reliable diagnostic methods becomes important.

PCR technique could be a potentially useful method for the diagnosis of brucellosis since it could detect the bacteria in samples even if highly contaminated with other microorganisms. In addition, PCR technique could detect more infected animals compared to serological methods (Romero and Lopez-Goni 1999; Leal-Klevezas et al., 2000; Cortez et al., 2001 and Ayman and Nermeen 2010).

The aim of the current study was to use multiplex PCR technique for simultaneous accurate detection and differentiation of Brucella and Yersinia enterocolitica O:9 to avoid false culling of seropositive animals and subsequent economic losses.

\section{MATERIALS and METHODS}

Animals: A total of 45 diseased and apparently healthy cows collected from some veterinary clinics at El-Sharkia governorate were used for this work.

\section{Sampling:}

A total of 118 different samples were collected. The samples were classified as follow (45 serum samples, 45 blood samples, stomach contents of 18 aborted feati and 10 fecal samples) the detailed data reported in Table (1). Serum samples were collected in clean dry centrifuge tubes without anticoagulant, left to clot, centrifuged at $1500 \mathrm{xg}$ for 20 minutes for serum separation used for serological investigation kept at $20^{\circ} \mathrm{C}$ until analyzed. Blood samples was collected on EDTA as anticoagulant used in PCR assay.

\section{Bacterial strains:}

Brucella abortus strain 19 and Yersinia enterocolitica O:9 were kindly provided by the Brucella Department Animal Health Research institute, Dokki, Giza used as control positive for PCR assay.

\section{I- Serological investigation:}

1. Buffered acidified plat antigen test (BAPAT): The test was applied according to (Anon 1984) where, any degree of agglutination within 8 minutes $(\geq 20$ IU $\mathrm{ml}^{-1}$ ) was considered positive and if no agglutination within 8 minutes was regarded as negative.

2. Rose-Bengal plate test (RBPT): The test was conducted according to (Alton et al., 1988) where, any degree of agglutination within 4 minutes $(\geq 25$ IU $\mathrm{ml}^{-1}$ ) was considered positive and if no agglutination within 4 minutes was regarded as negative.

3. Complement Fixation test (CFT): The test was performed according to (Ibrahim 1996) using G.Pig serum as a source of complement and a pretitrated amount of $2 \%$ sensitized sheep erythrocytes.
4. Indirect Enzyme Linked Immunosorbant Assay (ELISA): The test was applied according to (Alton et al., 1988). Briefly by using Brucella LPS as coating antigen and the tested sera diluted in 1/100 PBS (pH 7.2) were added. The plates incubated at $37^{\circ} \mathrm{C}$ for 30 minutes. After washing 200ul of conjugate were added then 200ul of freshly prepared OPD were added. Finally the plates were read spectrophotometrically at $492 \mathrm{~nm}$.

\section{II- Molecular investigation Multiplex Polymerase chain reaction:}

Extraction of crude DNA from bacteria: DNA template was prepared by boiling according to (OIE 2009) for brucella and according to (Balakrishna et al., 2012) for Yersinia enterocoltica O:9 finally centrifuged for $10 \mathrm{~min}$ and the supernatants were used as DNA templates for PCR amplification stored at -20 till use.

DNA extraction from stomach contents of aborted faeti: The procedure was applied according to (Cetinkaya et al., 1999). 300ul of stomach contents suspended in $300 \mathrm{ul}$ distilled water were incubated at $56^{\circ} \mathrm{C}$ for 45 minutes. $100 \mathrm{ul}$ of $2 \% \mathrm{SDS}$ and IM sodium hydroxide mixture and 50 ul PBS ( $\mathrm{pH} 7.4)$ were added to the suspension. The suspension was vortexed and boiled for 30 minutes and then left to cool. $100 \mathrm{ul}$ of $1 \mathrm{M}$ Tris- $\mathrm{HCl}$ ( $\mathrm{pH}$ 6. 8) was added to the suspension and it was again shaken vigorously and centrifuged at $11,600 \mathrm{~g}$ for 15 minutes. $300 \mathrm{ul}$ of the supernatant was transferred to another tube. DNA was purified by successive phenol, phenolchloroform-isoamyl alcohol (25:24:1), and chloroform-isoamyl alcohol extractions followed by precipitation with ethanol overnight at $-20^{\circ} \mathrm{C}$. The DNA was dissolved in $100 \mathrm{uL}$ of distilled water according to Maniatis et al. (1982).

The DNA purification from feces: was based on procedures developed by Gumerlock et al. (1991) and by Collins et al. (1993). Briefly, one gram of feces, was suspended in $10 \mathrm{ml}$ of phosphate buffered saline ( $\mathrm{pH}$ 7.4) and shaken for $5 \mathrm{~min}$, and sedimented for 30 min. One milliliter of supernatant was centrifuged at $13,0003 \mathrm{~g}$. The pellet was resuspended in $670 \mathrm{ml}$ of TE-sucrose (50 mM Tris-HCl [pH 8] $50 \mathrm{mM}$ EDTA, $20 \%$ sucrose), $300 \mathrm{ml}$ of SDS (10\%), and $30 \mathrm{ml}$ of proteinase $\mathrm{K}(20 \mathrm{mg} / \mathrm{ml})$. The mixture was incubated at 50C for $60 \mathrm{~min}$. DNA was extracted with phenol: chloroform and then precipitated with ice-cold ethanol; the DNA pellet was then dissolved in $50 \mathrm{ml}$ distilled water.

Extraction of DNA from blood samples: DNA was extracted from bovine blood samples according to Mukherjee et al. (2007) using a slight modification of a protocol published by Leal-Klevezas et al. (1995). 
Multiplex PCR: PCR reaction was performed in a total volume of $25 \mu \mathrm{l}$ with $5 \mu \mathrm{l}$ of the DNA template, 25 pmol of each oligonucleotide primer (Metabion international AG), of both brucella and yersinia detailed sequence of each primer shown in table (2), 12.5ul of $2 \mathrm{X}$ master mix and nuclease free water up to 25ul. The cycling protocol listed in Table (3).

The primers B4 and B5 were designed to amplify a target sequence of 223-bp within a gene of Brucella cell surface protein (BCSP) code for the production of a $31-\mathrm{kDa}$ membrane protein specific to the genus Brucella. Also, primer used to amplify a target sequence of 325-bp for Yersinia specific region of the 16S rRNA gene has been used to detect Yersinia spp.

\section{Analysis of PCR products:}

The analysis was carried out according to Sambrook et al. (1989) using $1.5 \%$ ethidium bromide stained agarose gel and visualized under ultraviolet transilluminator.

\section{RESULTS}

Results of serum samples investigated by different serological methods (Rose Bengal, BAPAT, CFT and ELISA) for detection of bovine brucellosis reported in
Tables (4) and (5) where the highest positive number of samples for brucella was obtained by BAPAT test (31samples out of 45 serum samples). On the other hand, RBPT test showed the lowest positive samples (23 samples out of 45 serum samples).

A number of seventy three samples (45 blood samples, 18 stomach contents of aborted fetii and 10 fecal samples) were subjected to investigation by multiplex PCR for amplification of Brucella cell surface protein (BCSP) \&16S rRNA genes of both Brucella \& Yersenia respectively. Results for positive amplification of expected amplicons 223-bp and 325bp of both Brucella and Yersenia enterocolitica O:9 are shown in Fig (1).

The results of multiplex PCR are presented in table (6) where out of 45 blood samples 19 samples gave positive amplification for Brucella, five samples gave positive amplification for Yersinia enterocolitica O:9 and two samples were positive for both. Table (5) also, demonstrates that three samples were positive for Yersinia out of 10 fecal samples while none were positive for Brucella. Moreover, 11 samples were positive for Brucella out of 18 stomach content samples and none were positive for Yersenia.

Table 1: Type \& number of samples.

\begin{tabular}{|c|c|c|c|c|c|c|}
\hline \multirow{2}{*}{ Animal status } & \multirow{2}{*}{ No. of animal } & \multicolumn{4}{|c|}{ Type \& number of Samples } & \multirow{2}{*}{$\begin{array}{c}\text { Total No. } \\
\text { of } \\
\text { samples }\end{array}$} \\
\hline & & Serum & $\begin{array}{l}\text { Blood on } \\
\text { (EDTA) }\end{array}$ & $\begin{array}{l}\text { Stomach } \\
\text { contents }\end{array}$ & Feaces & \\
\hline Apparently healthy & 7 & 7 & 7 & - & - & 14 \\
\hline Fevered & 10 & 10 & 10 & - & - & 20 \\
\hline Diarrheic & 10 & 10 & 10 & - & 10 & 30 \\
\hline Abortion & 18 & 18 & 18 & 18 & - & 54 \\
\hline Total & 45 & 45 & 45 & 18 & 10 & 118 \\
\hline
\end{tabular}

Table 2: Primers used in Multiplex PCR reaction of Brucella and Yersenia enterocolitica.O:9.

\begin{tabular}{cccc}
\hline Target & Name (strand) & Primer sequence (5 - 3) & Reference \\
\hline \multirow{2}{*}{ Brucella } & B4 F & 5'-TGGCTCGGTTGCCAATATCAA- 3' & $\begin{array}{c}\text { Baily et al., (1992) Mukherjee } \\
\text { et al., (2007) Moussa } \text { et al., } \\
\text { (2011) }\end{array}$ \\
\hline \multirow{2}{*}{ Yersinia } & B5 R & 5'-CGCGCTTGCCTTTCAGGTCTG- 3 & Balakrishna et al., (2012) \\
& 16S rRNA F & 5'-AATACCGCATAACGTCTTCG-3' & \\
\hline
\end{tabular}


$\underline{\text { Assiut Vet. Med. J. Vol. } 59 \text { No. } 139 \text { October } 2013}$

Table 3: Cycling protocol of multiplex PCR for amplification of BCSP \&16S rRNA genes of both Brucella \& Yersenia enterocolitica respectively.

\begin{tabular}{|c|c|c|c|c|c|}
\hline \multirow[t]{2}{*}{ Target } & \multirow[t]{2}{*}{ Amplicon size } & \multicolumn{3}{|c|}{ Cycling condition } & \multirow[b]{2}{*}{ No. of cycle } \\
\hline & & Step & Temp. & Time & \\
\hline \multirow[b]{2}{*}{ Brucella } & \multirow{2}{*}{$223 b p$} & Initial denaturation & $95^{\circ} \mathrm{C}$ & $5 \min$ & One cycle \\
\hline & & Denaturation & $94^{\circ} \mathrm{C}$ & $45 \mathrm{~s}$ & \multirow{3}{*}{35 cycles } \\
\hline \multirow{3}{*}{ Yersinia } & \multirow{3}{*}{$325 b p$} & Anealing & $55^{\circ} \mathrm{C}$ & $45 \mathrm{~s}$ & \\
\hline & & Extension & $72^{\circ} \mathrm{C}$ & $1 \mathrm{~min}$ & \\
\hline & & Final extension & $72^{\circ} \mathrm{C}$ & $10 \mathrm{~min}$ & One cycle \\
\hline
\end{tabular}

Table 4: Results of BAPA and RBPT on serum samples.

\begin{tabular}{|c|c|c|c|c|c|c|c|c|c|c|c|c|}
\hline \multirow{3}{*}{ Test } & \multicolumn{6}{|c|}{ BAPAT } & \multicolumn{6}{|c|}{ RBPT } \\
\hline & \multicolumn{4}{|c|}{ Positive scores } & \multirow{3}{*}{$-\mathrm{Ve}$} & \multirow{3}{*}{ Total } & \multicolumn{4}{|c|}{ Positive scores } & \multirow{3}{*}{$-\mathrm{Ve}$} & \multirow{3}{*}{ Total } \\
\hline & $1+$ & $2+$ & $3+$ & $4+$ & & & $1+$ & $2+$ & $3+$ & $4+$ & & \\
\hline Number & 8 & 8 & 14 & 1 & & & 3 & 12 & 7 & 1 & & \\
\hline Total & \multicolumn{4}{|c|}{31} & 14 & 45 & \multicolumn{4}{|c|}{23} & 22 & 45 \\
\hline
\end{tabular}

BAPAT $=$ Buffered Acidified Plate Antigen Test. $\quad$ RBPT $=$ Rose Bengal Plate Test.

Table 5: Results of CFT and ELISA on serum samples.

\begin{tabular}{|c|c|c|c|c|c|c|c|c|c|c|}
\hline \multirow{3}{*}{ Test } & \multicolumn{8}{|c|}{ CFT } & \multirow{2}{*}{\multicolumn{2}{|c|}{ ELISA }} \\
\hline & \multicolumn{6}{|c|}{ Positive titer reciprocals } & \multirow{3}{*}{$-\mathrm{Ve}$} & \multirow{3}{*}{ Total } & & \\
\hline & 5 & 10 & 20 & 40 & 80 & 320 & & & No. of $+\mathrm{Ve}$ & No. of -Ve \\
\hline Number & 5 & 3 & 6 & 7 & 1 & 2 & & & 26 & 19 \\
\hline Total & \multicolumn{6}{|c|}{24} & 21 & 45 & \multicolumn{2}{|c|}{45} \\
\hline
\end{tabular}

Table 6: Results of Multiplex PCR.

\begin{tabular}{ccccc}
\hline Type of samples & No. of samples & No. of +ve Br & No. of +Ve Y.O:9 & No. of Mixed \\
\hline Blood on EDTA & 45 & 19 & 5 & 2 \\
\hline Stomach content & 18 & 11 & 0 & 0 \\
\hline F.S & 10 & 0 & 3 & 0 \\
\hline Total & 73 & 30 & 8 & 2 \\
\hline
\end{tabular}




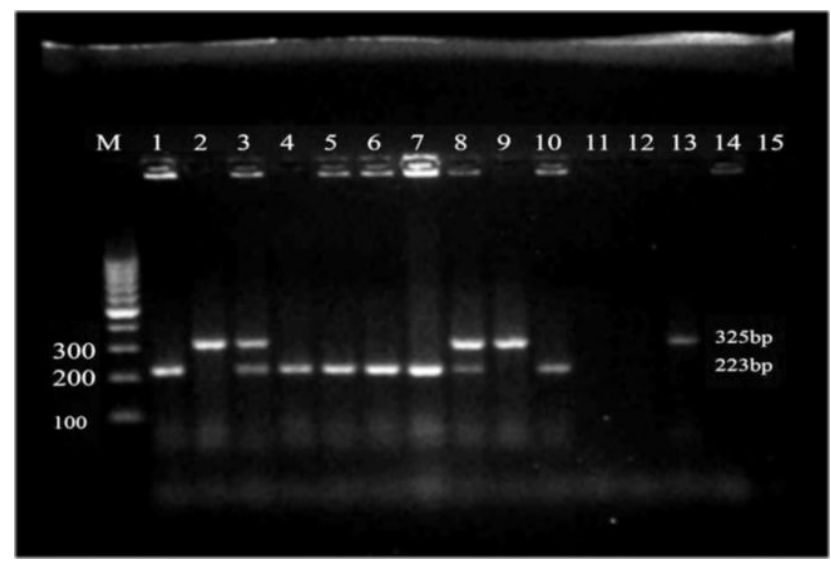

Fig 1: Shows ethidium bromide stained 1.5\% agarose gel electrophoresis of Multiplex PCR products.

Lane M: 100bp DNA Ladder

Lane 1: Brucella positive control 223bp

Lane 2: Yersinia positive control 325bp

Lane 3: Mixed positive control

Lane 4- 14: Samples (lane 4-7 and lane 10 positive for Brucella, lane 8 positive for both , lane 9,13 positive for Yersinia and lane 11,12, 14 negative samples)

Lane 15: Negative control

\section{DISCUSSION}

Accurate diagnosis of brucellosis in any species is fairly straightforward but may be very difficult in some cases. Because of the problems with isolation and identification of Brucella culture which relies upon a great deal of phenotypic traits: inefficiency, cost, danger and other factors, most laboratories prefer to use molecular biology as a diagnostic tool based on the amplification of genomic targets through different polymerase chain reaction (PCR) approaches (Fernando et al., 2010). Moreover, these molecular approaches will soon be at the point of replacing actual bacterial isolation. It is rapid, safe and cost effective (Nielsen and Yu 2010).

Detection of Yersinia enterocolitica in clinical samples is still not sensitive and fast enough. Polymerase chain reaction (PCR) offers the advantages of sensitivity, specificity, and rapidity (Odinot et al., 1997).

Inaccurate serological results causing incorrect diagnoses are a continuous problem when testing for infectious disease agents in animals or in human beings. Because of the genetic diversity of populations, some animals will respond with low antibody levels to exposure to Brucella sp., resulting in false negative results. Exposure to cross-reacting microorganisms may cause elevated antibody levels for various periods of time resulted in a false positive serological reaction, a major diagnostic problem in some areas where such microorganisms are endemic (Nielsen and Yu 2010).

Indirect enzyme-linked immunosorbent assays (ELISA) using S-LPS extracts or its O-chain have been extensively studied (Nielsen 2002) and may replace the Rose Bengal test (RBT) and CFT. These tests are the most sensitive for detecting cattle brucellosis, but they may yield false positive results with many other bacteria but only Yersinia enterocolitica O:9 is a significant cause of falsepositive serological reactions (FPSR) in the diagnosis of bovine brucellosis (Gerbier et al., 1997). Thus, $Y$. enterocolitica O:9 infections in cattle are troublesome and generate considerable additional costs in surveillance programs (Muñoz et al., 2005).

Therefore, the aim of this work is to fulfill towards serological investigation and molecular differentiation between Brucella and Yersinia enterocolitica 0:9 infections in cattle.

In our serological investigation the highest number of positive cattle was achieved by the presumptive BAPA. This test is supposed to exclude negative cases from further serological testing (Alton et al., 1988) and positive cases should be confirmed. The RBPT behaved ineffectively in this study where it detected slightly less positive animals than did the confirmatory CFT. This could be attributed to the high specificity of the CFT that allows for a very low positive cutoff of $20 \mathrm{IU} \cdot \mathrm{ml}^{-1}$ and hence a sensitivity slightly superior than that of the RBPT whose cutoff value is $25 \mathrm{IU}_{\mathrm{m}} \mathrm{m}^{-1}$. Additionally, the CFT is more selective than the RBPT in terms of the detection of complement fixing $\mathrm{IgG}_{1}$ (Ibrahim, 1982) which happens to be agglutinogenic at the acidic $\mathrm{pH}$ of the RBPT (Alton et al., 1988) As expected from ELISA, its sensitivity was somewhere between the BAPA and the RBPT. This sensitivity is attributed to the fact that ELISA is a primary binding assay that detects mainly 
all $\mathrm{IgG}$ isotypes regardless of their biological activity (Alton et al., 1988).

Multiplex-PCR assays that performed in our work were standardized to amplify fragments of $223 \mathrm{bp}$ and $325 \mathrm{bp}$ corresponding to gene encoding a $31 \mathrm{kDa}$ cell surface protein (BCSP) of Brucella and 16s rDNA gene as target for the detection of Yersinia species. The genus specific primer of the gene encoding a 31 $\mathrm{kDa}$ cell surface protein (BCSP) of brucella have been used with success to diagnose infection with brucella by various authors (Mukherjee et al., 2007; Ayman and Nermeen 2010; Moussa et al., 2011 and Jabbar et al., 2012), none of whom ever related false positives. Also, a general-primer used to amplify a target sequence of 325-bp for Yersinia specific region of the 16S rRNA gene has been used to detect Yersinia spp., especially in blood samples (Sen and Asher 2001) and was recommended by (Arora et al., 2012).

The result of multiplex PCR revealed that 19 blood samples gave positive amplification of 223bp for brucellosis and seven positive amplification of $325 \mathrm{bp}$ for Yersinia enterocolitica O:9 representing 26.92\% of total positive Brucella of which two samples were positive for both Yersinia and Brucella, representing $7.69 \%$ this results agree with previous results of (Nagaraju et al., 2001) and (Marcin et al., 2012).

Also, multiplex PCR assay revealed the presence of three positive feacal samples for Yersenia enterocolitica 0:9 in serologically positive Brucellosis this results confirm the previous results of (Reynaud et al., 1993) who could isolate Yersinia enterocolitica 0:9 from stool of cattle and goats had positive tests for brucellosis.

\section{CONCLUSION}

We can conclude that multiplex PCR assay for amplification of BCSP \&16S rRNA genes of both Brucella \& Yersenia can be successfully used for simultaneous detection and differentiation of Brucella and Yersinia enterocolitica O:9. Y. enterocolitica O:9 infections in cattle are seem to be a troublesome and generate considerable additional costs in Brucellosis surveillance programs. This study should be extended to a large scale population for proper identification of epidemiological status of cattle herd.

\section{ACKNOWLEDGMENTS}

The authors thank prof. Dr/ Saad-M.A.M. Animal R.R. Institute El-Haram, Dr/ Ashraf E. Sayour and Dr/ Nour H. Abdel Hamid for their collaboration.

\section{REFERENCES}

Alton, G.G.; Jones, L.M.; Pietz, D. and Angus, R.D. (1988): Techniques for Brucellosis Laboratory. INRA Publications, Paris, France.

Anon. (1984): Supplemental test procedures for the diagnosis of brucellosis (Diagnostic Reagents Manual 65-E) National Veterinary Services Laboratories, Ames, Iowa., USA.

Arora, D.; Mehta, N. and Saini, R. (2012): Epidemiological pattern and detection of Yersinia enterocolitica in foods of animal origin: a review. Journal of Cell and Tissue Research Vol. 12 (1) 3021-3028.

Ayman, A. and Nermeen, H. (2010): Detection of Brucella abortus in Bovine Milk by Polymerase Chain Reaction. ACTA VET. BRNO, 79: 277-280.

Balakrishna, K.; Radhika, M.; Murali, H.S.; Batra, H.V. and Bawa, A.S. (2012): Specific identification of pathogenic Yersinia enterocolitica by monoclonal antibodies generated against recombinant attachment invasion locus (rAil) protein. World $\mathbf{J}$ Microbiol Biotechnol 28: p 533-539.

Baily, G.G.; Krahn, J.B.; Drasar, B.S. and Stoker, N.G. (1992): Detection of Brucella melitensis and Brucella abortus by DNA amplification. J Trop Med Hyg 95, 271-275.

Cetinkaya, B.; Ongor H.; Muz, A.; Ertas, H.B.; Kalender, H. and Erdogan, H.M. (1999): Detection of Brucella species DNA in the stomach content of aborted sheep fetuses by PCR. Veterinary Record 144, 239-240.

Cheasty, T.; Said, B.; Jiggle, B. and Threlfall, J. (1998): Yersinia species associated with diarrhoeal disease in the United Kingdom during the period 1990-1996. Nederlands Tijdschrift voor Medische Microbiologie 6, Suppl. II, S11.

Collins, D.M.; Stephens, D.M.; and de Lisle, G.W. (1993): Comparaison of polymerase chain reaction tests and faecal culture for detecting Mycobacterium paratuberculosis in bovine faeces. Vet. Microbiol. 36:289-299.

Cortez, A.; Scarcelli, E.; Soares, R.M.; Heinemann, M.B.; Sakamoto, S.M.; Genovez, M.E.; Ferreira, F. and Richtzenhain, L.J. (2001): Detection of Brucella DNA from aborted bovine foetuses by polymerase chain reaction. Aust Vet J 79: 500-501.

Erika, C.; Elisabeth, B.; Susanne, T.L. and Karin, A. (2012): Yersinia enterocolitica serotype O:9 cultured from Swedish sheep showing serologically false-positive reactions for Brucella melitensis. Infection Ecology and epidemiology, 2 pp 1-7. 
Fernando, P.P.; Klaus, N.; Luis, E.S. and Wei, L. Yu. (2010): Diagnosis of Brucellosis. The Open Veterinary Science Journal, 4, 46-60.

Gerbier, G.B.; Garin-Bastuji, R.; Pouillot, P.; Very, C.C.; Berr, V.; Dufour, B. and Moutou, F. (1997): False positive serological reactions in bovine brucellosis: evidence of the role of Yersinia enterocolitica serotype 0:9 in a field trial. Vet. Res. 28:375-383.

Gorvel, J.P. (2008): Brucella: a Mr "Hide", converted into Dr Jekyll. Microbes Infect; 10: 1010_13. Review.

Gumerlock, P.H.; Tang, Y.J.; Meyers, F.J. and J. Silvia, Jr. (1991): Use of the polymerase chain reaction for the specific and direct detection of Clostridium difficile in human feces. Rev. Infect. Dis. 13:1053-1060.

Henk, L.S. and S. Manzoor, K. (2005): Brucellosis in India: a deceptive infectious disease. Indian $\mathrm{J}$ Med Res 122, pp 375-384.

Ibrahim, S.I. (1996): Serological monitoring of ewes experimentally infected with Brucella melitensis biovars. J. Egypt. Vet. Med. Asso. osi 56 (II)13-24.

Jabbar, A.A.; AL-Sa'aidi, M.; Al-Rodh, A. and Ali, A.N. (2012): Clinical, serological, hormonal, bacteriological and molecular detection of brucellosis in aborted cows and buffalos. International Conference on Applied Life Sciences. 10-12, 327-336.

Kapperud, G. (1991): Yersinia enterocolitica in food hygiene. Int J Food Microbiol 12:53-66.

Leal-Klevezas, D.S.; Martinez-Vaquez, I.O.; LopezMerino, A. and Martinez-Soriano, J.P. (1995): Single-step PCR for detection of Brucella spp. from blood and milk of infected animals. J Clin Microbiol 33, 3087-3090.

Leal-Klevezas, D.S.; Martinez-Vazquez, I.O.; GarciaCantu, J.; Lopez-Merino, A. and MartinezSoriano, J.P. (2000): Use of polymerase chain reaction to detect Brucella abortus biovar 1 in infected goats. Vet Microbiol 75: 91-97

Lübeck, P.S.; Skurnik, M.; Ahrens, P. and Hoorfar, J. (2003): A Multiplex PCR-Detection Assay for Yersinia enterocolitica Serotype O:9 and Brucella spp. Based on the Perosamine Synthetase Gene. Advance in Experimental Medicine \& Biology, 1, vol. 529 Genus Yersinia, part VI pp 451-454.

Maniatis, T.; Fritsch, E.E. and Sambrook, J. (1982): In: Molecular cloning: a laboratory manual. Cold Spring Harbor, NY: Cold Spring Harbor Laboratory.

Marcin, W.; Krzysztof, S. and Wojciech, I. (2012): Isolation Of Yersinia Enterocolitica O:9 From Cows Positive In Serological Examination Of Bovine Brucellosis. Bull Vet Inst Pulawy 56, 473-477.
Moussa, I.M.; Omnia, M.E.; Amin, A.S.; Ashgan, M.H. and Selim S.A. (2011): Evaluation of the currently used polymerase chain reaction assays for molecular detection of Brucella species. African Journal of Microbiology Research 5(12), pp. 1511-1520, 18 June.

Mukherjee, F.; Jain, J.; Patel, V. and Mrinalini, N. (2007): Multiple genus-specific markers in PCR assays improve the specificity and sensitivity of diagnosis of brucellosis in field animals. Journal of Medical Microbiology 56, 1309-1316.

Muñz, P.M.; Marı'n, C.M.; Monreal, D. Gonza'lez, D.; Grain-Bastuji, B.; Diaz, R.; Mainar-Jaime, R.C.; Moriyon, I. and Blasco, J.M. (2005): Efficacy of Several Serological Tests and Antigens for Diagnosis of Bovine Brucellosis in the Presence of False-Positive Serological Results Due to Yersinia enterocolitica O:9. Clinical and Diagnostic Laboratory Immunology, Jan. 2005, P. 141-151.

Nagaraju, N.R.; Isloor, S.; Sathyanarayana, Rao, M. and Rajasekhar, M. (2001): Prevalence of Yersinia Antibodies in Serodiagnosis of Bovine Brucellosis. Online Journal of Veterinary Research 5: 197-204.

Nielsen, K. (2002): Diagnosis of brucellosis by serology. Vet. Microbiol. 90: 447-459.

Nielsen, K. and Yu WL. (2010): Serological diagnosis of brucellosis. Contributions, Sec. Biol. Med. Sci., MASA, XXXI, 1, p. 65-89.

Odinot, P.T.; Jacques, M.EG.M.; Curfs, Jo H.A.J.; Jacomina, A.A.; Hoogkamp-Karstanje, M.D. and Willem, J.G.M. (1997): Two-Step Polymerase Chain Reaction Assay for Detection of Yersinia Species in General and of Pathogenic Yersinia enterocolitica Strains Specifically. International Journal of Infectious Diseases 1, 4, p 206-211.

OIE (2009): Ch. 2.4.3. Bovine brucellosis. In: Manual of diagnostic tests and vaccines for terrestrial animals, pp. 624-659. OIE, Paris, France.

Raúl, C. Mainar-Jaime; Pilar, M.M.; María, J.; de Miguel, J.; Maria, J.G.; Clara, M.M.; Lgnacio, M. and Jose, M.B. (2005): Specificity dependence between serological tests for diagnosing bovine brucellosis in Brucella-free farms showing false positive serological reactions due to Yersinia enterocolitica 0:9. Can Vet J; 46:913-916.

Reynaud, A.; Delmas, C.; Vidon, J.M.; Marty-Garrec, M. and Dubourdieu, V. (1993): Presence of Yersinia enterolitica O:9 in fecal samples of Brucella abortus ruminants revealing atypical serological reactions against antigens. Medecine et Maladies Infectieuses; 23(S): 516-9.

Romero, C. and Lopez-Goni, I. (1999): Improved method for purification of bacterial DNA from 
bovine milk for detection of Brucella spp. by PCR. Appl Environ Microbiol 65: 3735-3737.

Sambrook, J.E.; Fritsch, E.F. and Maniates, T. (1989): Molecular coloning laboratory manual. $2^{\text {nd }}$ edition.
Sen, K. and Asher, D.M. (2001): Multiplex PCR for detection of Enterobacteriaceae in blood. Transfusion 41:1356-1364.

\title{
التمييز السيرولوجى والجزيئي بين الإصابة بالبروسيلا واليرسينيا إنتيروكوليتيك 0:9 في الأبقار \\ نادية عبد العظيم شلبي ، جيهان عبد الله محد جعفر ، محمد على محمد بلران \\ Email: (jehan.gafer@gmail.com)
}

\begin{abstract}
يعتبر مرض الإجهاض المعدي (البروسيلا) من أهم الأمر اض المشتركة التي لاتزال محل اهتمام كل من الأطباء

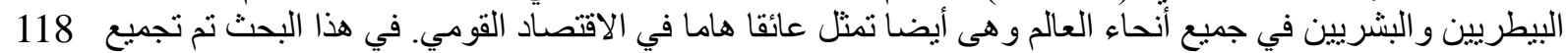

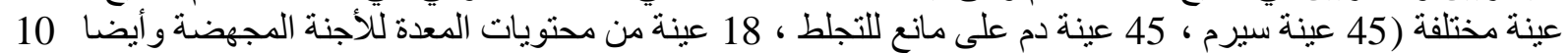

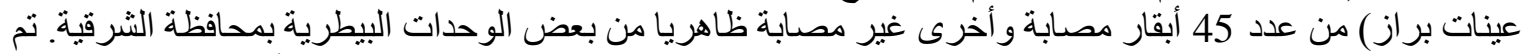

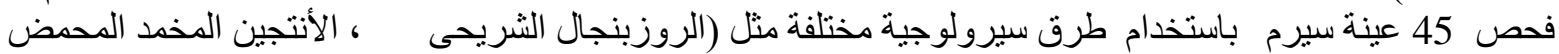

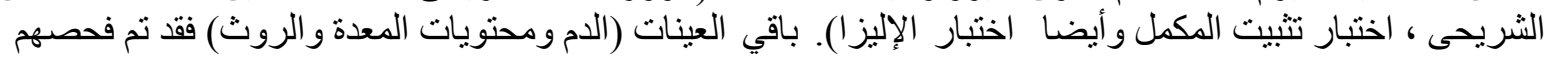

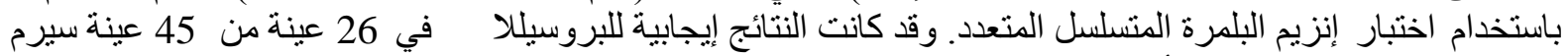

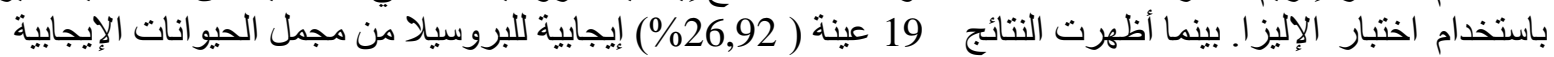

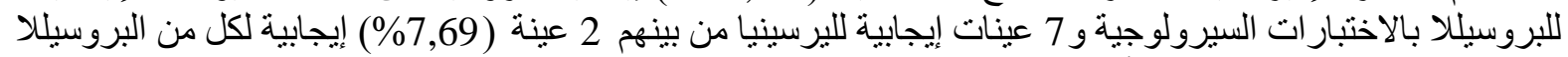

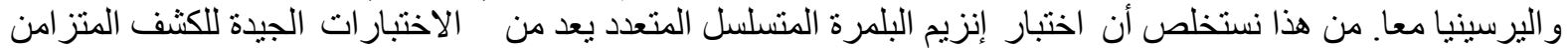
الدقيق و السريع للبروسيلا و اليرسينيا وأيضا التفرقة بينهما.
\end{abstract}

